\title{
Cultural Third Sector Organizations and Local Development: New Actors and Tools for Urban Regeneration in Deprived Contexts
}

\section{ABSTRACT}

The importance of the creative and cultural capital in the economic development of postindustrial inner cities has been widely demonstrated by urban development literature as it interacts with the physical environment and sustains regeneration processes. However, also in depressed and peripheral neighbourhoods, creative firms, museums, nonprofit organizations, cultural associations, and independent artists can be identified as actors of substantial urban revitalization. In this regard, understanding the potential of art-based third sector organizations in the emergence of virtuous patterns in urban regeneration strategies is even more crucial. Starting from an institutional economics perspective, the main purpose of this contribution is to review the literatures about the not-for-profit sector and the cultural and creative economy, in order to merge the two previous approaches through the common ground of social innovation. Within the general framework of urban redevelopment processes through specific not-for-profit models and tools, this article also aims to build questions about the role these actors may play as engines of urban regeneration to be addressed through further empirical research.

\section{KEY-WORDS}

THIRD SECTOR, CULTURAL ECONOMICS, SOCIAL INNOVATION, URBAN REGENERATION 


\section{Introduction}

Which is the potential of art-based third sector organizations in transforming the patterns of depressed peripheries? In order to understand if these organizations are able to develop virtuous strategies of urban, social and economic regeneration, we firstly need to build a theoretical framework around the institutional economic literature, identifying three main pillars: Gunnar Myrdal, Albert Hirschman and Karl Polanyi. Secondly, in order to underline the role third sector organizations may play socially and economically speaking, we focus on the literature about those entities that form part of it and the theories that explain their birth and development. Thirdly, we concentrate on the literature about the cultural and creative economy and its fundamental role in urban regeneration and local development. Finally, the main proposal is to merge two strands of literature around the common ground of social innovation. Starting from this institutional economics framework, we try to propose questions about the role that cultural-based third sector organizations may play in the urban regeneration of depressed areas to be addressed through further empirical research.

However, before facing the aspects underlined above, we need to focus on the spatial contexts in which we move: destruction of local identity, loss of social cohesion, social exclusion, physical decadence are evident in many urban districts commonly defined as "urban peripheries" and recognized through solely negative aspects with no possibilities of rehabilitation. But this image is not completely true as both positive and negative elements coexist within urban peripheries from physical-spatial and socio-economic points of view. In fact, despite negative phenomena that undoubtedly persist, peripheral neighbourhoods are much more multifaceted and complex than they may appear.

Actually, peripheries may also be considered as places where innovative forms of local selforganization, re-developed sense of local community, new cultural references and artistic expressions may rise. Specifically from a cultural viewpoint, it is worth underlining the different reasons that lead to consider peripheries as spaces able to reinvent themselves: (1) concentration of mainstream cultural offerings in more institutionalized and centric neighbourhoods; (2) particular social and economic conditions and dynamics; (3) presence of urban voids and accessible properties, lands and infrastructures prices; (4) generation of localization flows able to multiply themselves; (5) sentiments of resentment, dissent and manifestation against a system that seems having abandoned local residents.

The sense of deprivation caused by this marginality leads to retake control of abandoned urban spaces, in many cases through a deep collaboration between local communities and not-for-profit actors. And, generally speaking, the most utilized tool for this (re)appropriation is that of the arts, culture and creativity that may rise innovation in social and economic terms through integration, participation and dialogue among all the actors involved. In terms of urban regeneration, in particular, urban creativity, underground art and submerged culture may activate "processes of equilibrium" based on the creative industry and its potential of transformation of peripheral areas (Patti and Polyak, 2018). 
The analysis of the interactions among third sector organizations, creative and cultural economy and urban revitalization is basically important in order to deeper comprehend contributions and limits that these organizations meet in dealing with the economic and human development of communities living in conditions of social, economic and spatial depression.

\section{Theoretical framework}

First of all, Myrdal (1939) explains underdevelopment as a movement of resources: in poor areas, young, talented, ambitious and educated people leave for more developed areas where they can earn more and enhance their skills. This brain drain leaves a small tax base to generate funds for needed services and regional development, while domestic savings tend to be invested where the returns are likely to be higher. He argues that the contraction of markets in an area tends to have a depressing effect on new investments, which in turn causes a further reduction of income and demand, implying a net movement of enterprises and workers towards other areas. Consequently, fewer local taxes are collected in a time when more social services are required, a vicious downward cumulative cycle starts and a trend towards a lower level of development is reinforced, with a subsequent status of non-equilibrium. Myrdal (1957) states that specific forces can be considered as those guiding the evolution of social processes and that, in many developed regions, these effects are competing for driving migration flows. The play of these forces in the market normally tends to increase the inequalities between regions: the limited advantages of backward regions are insufficient to offset agglomeration advantages of centres. In this regard, the main influence on the rate of growth of underdeveloped regions is the induced effect of growth in advanced regions, which can be divided into backwash and spread effects.

Backwash effects are all those "relevant adverse changes, caused outside the locality [included] the effects via migration, capital movements, and trade as well as all the effects via the whole gamut of other social relations exemplified above [non-economic factors]" (Myrdal, 1957: 30). In other words, backwash effects imply the idea that if one particular area in a country starts growing, it causes the gravitation of people, human and physical capital from other parts of the country towards this growing centre.

Spread effects, conversely, involve the idea that economic development effects in one place spread to its suburbs and all the neighbouring areas. Spread effects could arise from increased demand by the centre by the emergence of new secondary centres of expansion or by the fact that industrialization may inculcate "a new spirit of rationalism, enterprise, discipline, punctuality, mobility, and efficiency" (Myrdal, 1963: 31). Depending on which set of effects predominates in a setting, the cumulative process could evolve upward, as in the "lucky" regions, or downward, as in the "unlucky" ones.

Similarly to Myrdal, Hirschman (1958) defines backwash and spread effects as "polarization" and "trickling down" effects. However, here we focus on a further argument developed by Hirschman 
(1970) that refers to "exit" and "voice": members of an organization (firms, voluntary associations, trade unions, political parties, nations or any other form of human grouping), have essentially two possible responses when they perceive that the organization is demonstrating a decrease in quality or benefit, i.e. they can "exit" (withdraw from the relationship); or, they can "voice" (attempt to repair or to improve the relationship through complaints or proposals for change).

Actually, Hirschman stresses that these two categories reflect the fundamental division between economics and politics (exit belongs to the former dimension, voice to the latter). In fact, referring to the relation between customers and business firms, the consumer who is dissatisfied with the product of one firm shifts to another and uses market to defend his welfare or to improve his position (Hirschman, 1970). What are particularly interesting in Hirschman's concept of voice are the conditions under which this option makes an effective appearance, either as a complement to exit or as a substitute for it. For members of an organization, voice means making an attempt at changing practices, policies and outputs of the organization to which they belong rather than to escape from it. However, the voice option is the only way in which dissatisfied members can react when the exit option is unavailable such as in family, tribe, state or church. Of course, compared to exit, voice is conditioned by the influence and the bargaining power that members can bring within the organization.

However, other than exit and voice, Hirschman also recalls a third concept, that of "loyalty" as a means to understand the conditions favouring the coexistence of exit and voice. The presence of loyalty, in fact, makes exit less probable as it can be conceived as a postponement of the leaving option in spite of dissatisfaction. The importance of loyalty, then, is that it not only postpones exit and activates voice, but it can also neutralize, within certain limits, the tendency of the most quality-conscious customers or members to be the first to exit. Indeed, through loyalty, "members may be locked into their organizations a little longer and thus use the voice option with greater determination and resourcefulness than would otherwise be the case" (Hirschman, 1970: 76).

So far, the theories of Myrdal and Hirschman pioneered the identification of the basic reasons why development is apt to be localised in space and to expose the nature and mechanisms through which its impulses are diffused. However, the concepts of backwash/polarization and spread/ trickling down effects as sources of development-underdevelopment may be also applied to urban areas: actually, several scholars recognized the presence of these sources at the urban scale in the concepts of "centripetal and centrifugal forces". Colby (1933) first stresses that the contemporary city is a dynamic organism constantly in a process of evolution that involves both a modification of long-established functions and the addition of new functions. Apparently, these developments of functions, forms and patterns are governed by a definite set of two groups of forces: centripetal forces hold certain functions in the central zone and attract others to it; centrifugal forces induce functions to migrate from the central zone towards its periphery. While centripetal forces "focus on the central zone and make that zone the centre of gravity for the entire urbanized area", centrifugal forces "are made up of a combination of uprooting impulses in the central zone and attractive qualities of the periphery" (Colby, 1933: 1). Furthermore, an urban area can be divided into: an 
inner or nuclear zone; a second or middle zone; and an outer or peripheral zone, so that urban functions migrate from a zone to another and from one part to another of the same zone.

However, a further consideration on the mechanisms that regulate the allocation of assets and resources and the failure both of the market and the state in playing the role of "fair allocator" is needed. In this regard, Polanyi (1944) states that, as self-regulating markets do not work, the need for governments' intervention to reduce markets' deficiencies and the pace of change are basically important in determining socio-economic and political consequences. In particular, Polanyi stresses the concept of "integration [that] is present in the economic process to the extent that those movements of goods and persons which overcome the effect of space, time, and occupational differentials are institutionalized so as to create interdependence among the movements" (Polanyi, 1977: 35). Although Polanyi explicitly refers to these forms of integration as stated above, it has been argued that they can be identified as types of the economy's social organization of acquisition and allocation of productive resources (Polanyi, 1977). Indeed, they serve to locate the economy in society, identifying the kinds of institutional, social, political, and economic sanctions that fix rights and obligations in the economic process. The forms of integration that Polanyi identifies are redistribution, exchange and reciprocity and represent the patterns made by the movements of goods and persons in the economy. Basically, while "redistribution stands for a movement towards a centre and out of it again", implying a dependence on a recognized centre (a state-centric system of resource allocation), "exchange represents a movement [...] between any two dispersed or random points in the system" (Polanyi, 1977: 36), referring to a market system where people exchange goods on the assumption that each makes the most of it (a market-centric system of resource allocation).

However, Polanyi describes a third movement: reciprocity is "the movement of goods and services [...] between corresponding points of symmetrical arrangement" (Polanyi, 1977: 36), implying the presence of symmetrically placed groups whose members can behave similarly toward one another in economic matters. Actually, the main characteristic of this type of organization is the fact that the movement of resources in and out of the economy is to be found in the societal structure that has the function of ordering relations among people in the economic process. This reciprocity situation is typical of relations in the family, in the kinship system, but also between friends, neighbours, members of voluntary associations, peer groups and the like. Thus, the movement of resources in the economic process is determined by the general expectations about the behaviour imposed by existing and functioning social institutions, implying the fundamental importance of behavioural norms that characterize a particular social structure.

In conclusion, in a situation in which the self-regulating market disentangles itself from society and erodes humanity and reciprocity in relations and where state-centred policies of redistributive nature are not effective in restoring the central role of society, new and different mechanisms and actors seem to raise in order to reduce these negative effects. In particular, when both redistribution and exchange mechanisms fail to efficiently allocate resources among all members of society, mechanisms of reciprocity and organizations that pursue objectives other than profit seem to be established in order to respond to state and market failures. In this regard, the role that third 
sector organizations may play should be further emphasized in many respects: (1) in their ability to revitalize peripheral areas, attracting assets and resources from other areas (Myrdal, 1957); (2) in their aptitude to give "voice" (Hirschman, 1970) to deprived communities, asking for economic, social and cultural resources and opportunities; (3) in their capacity to efficiently allocate resources among members, non-members and the community in general (Polanyi, 1977).

\section{The nonprofit and third sectors}

Several theories were advanced to explain the economic role of nonprofit organizations, especially focusing on the demand side. The "public goods theory" (Weisbrod, 1975; 1977; 1988), explains the existence of nonprofits from the concepts of the "median voter" and the "demand heterogeneity": nonprofits are established to satisfy the unfilled demand for public goods that government officials leave unmet as they, in seeking to maximize their chances of re-election, only satisfy the demand of the largest segment of the electorate. Furthermore, the "demand heterogeneity" is understood as the demand for public goods and the extent to which this demand is similar or different across the population: the amount of public goods provided by the nonprofit sector depends on the degree to which the public sector is able to satisfy the diverse demands of its constituents. In contrast, the "trust-related" or "contract failure theory" (Hansmann, 1980) takes place from the idea that nonprofits typically arise in situations in which consumers feel unable to evaluate accurately the quantity or quality of the service a firm produces for them. In fact, a nonprofit offers customers the advantage that those who control the organization are constrained in their ability to benefit personally from providing low-quality services and thus have less incentive to take advantage of their customers (Hansmann, 1987). This advantage is the signal of trustworthiness that arises from the non-distribution constraint that characterizes the nonprofit as "an organization that is barred from distributing its net earnings, if any, to individuals who exercise control over it, such as members, officers, directors, or trustees" (Hansmann, 1980: 838). Thus, the non-distribution constraint makes that nonprofits appear more trustworthy than for-profits under conditions of high transaction costs and strong moral hazard.

Conversely, "entrepreneurship theories" try to explain the existence of nonprofits from a supplyside perspective. Young (1983), James (1987) and Rose-Ackerman (1996) argue that (1) nonprofits may not be interested in profits in the first place as their objective function may lay elsewhere and assume non-monetary forms; (2) the provision of services may not be the real reason for the organization's existence as these activities may serve as means for achieving other goals (Anheier, 2014). On the other hand, the "stakeholder theory" (Ben-Ner, 1986) recognizes that nonprofits are founded by social entrepreneurs who are not motivated primarily by profit and refer to all the interested parties on both the demand and the supply side as stakeholders: nonprofits raise to provide consumers with direct control over the firm from which they purchase goods or services. Furthermore, Ben-Ner and Van Hoomissen (1992) state that the most important supply factor is 
the ability of some demand-side stakeholders to ensure that a specific nonprofit performs according to their wishes within economic feasibility constraints. Finally, the "voluntary failure theory" developed by Salamon (1995) argues that the government and the nonprofit sectors are much more frequently partners rather than rivals and that the government does not displace nonprofits but, conversely, supports and sustains extensively this sector in terms of monetary, indirect and other support. On the other hand, the "social origins theory" (Salamon and Anheier, 1998) aims to explain the variations in size and composition of the nonprofit sector cross-nationally, suggesting that the nonprofit sector across countries reveals different historical "moorings" and social and economic "shapes".

Differently from the "American" approach, "European" scholars tend to identify the third sector with the "social economy" which gathers enterprises from cooperative movements, mutual benefit and insurance societies, foundations and nonprofits that have some common organizational and governance principles, instead of maximizing and distributing profits to shareholders or members. Although they may receive public subsidies to fulfil their mission, they are clearly distinct from the public sector, are self-governed and private and are mainly based on the rule "one member, one vote" in their general assembly (Defourny and Nyssens, 2010). Actually, the term "third sector" is mostly used to define a sector located between the public and the private ones, becoming a meeting point mainly for the nonprofit sector and the social economy. Despite the considerable diversities among the types of entities and behaviours, the European third sector can be considered as composed by: (1) forms of individual or collective action outside the for-profit businesses, government or households; (2) values primarily generated for the broader community other than oneself; (3) actions pursued voluntarily and without compulsion; (4) the belonging organizations identified as nonprofits, mutuals, social enterprises and the civil society (Defourny and Pestoff, 2008).

In this regard, one of the most accepted definitions of "social economy" is that of Defourny (2001) who sees it in terms of two main approaches: (1) the legal-institutional approach has its fundamental components in cooperative-style enterprises, mutual-type organizations and associative organizations (with a wide variety of legal forms such as associations, nonprofits, voluntary, non-governmental, foundations, charities and the like, in which making a profit is not the essential purpose); (2) the normative approach, conversely, emphasises those principles that social economy organizations have in common and that distinguish them from private and public sector entities, especially their productive purpose and internal structure. From here, combining the legal-institutional and the normative approaches, Defourny states that "the social economy includes economic activities carried out by cooperatives and related enterprises, mutual societies and associations whose ethical stance is represented by the following principles: the aim of serving members or the community, rather than generating profit; independent management; a democratic decision-making process; the primacy of people and labour over capital in the distribution of income" (Defourny, 2001: 7).

Differently, the solidarity-based economy can be broadly defined as a perspective centred on all production, distribution and consumption activities contributing to the democratization of the 
economy based on citizen commitments and a public engagement in civil society. This approach stresses the predominance of reciprocity over exchange and redistribution principles within the emergence of economic initiatives, as well as the hybridization of market, non-market and nonmonetary resources in their consolidation and development. This concept is associated to a large degree with the major growth of third sector organizations in the production and distribution of the so called "social or merit goods", i.e. those goods for which there is broad social and political consensus that they are essential to a decent life and must therefore be made available to the entire population, irrespective of income or purchasing power. Concretely, this concept of solidarity economy has its roots in Polanyi's idea that market liberalization involves a "double movement" whereby those negatively affected react in various ways to deal with vulnerability and insecurity and to ensure social protection.

In this vein, a considerable body of work appeared around the concept of "social enterprise": the socio-political and economic context of the 1980s made the emergence of social enterprises institutionally possible as the hegemony of neoliberal economic ideology and its focus on enterprising cultures and societies was contrasted by the rise of counter hegemonic tendencies that questioned the values of laissez-faire by placing societal and environmental values at the centre of social and economic development paths. Consequently, the reaction of groups of citizens dissatisfied both by the public supply and the market provision of services contributed to shape the social enterprise as an institutional arrangement that facilitates the balancing of demand for these services with the supply of them.

One of the most comprehensive definitions of "social enterprise" elaborated by the EMES network (Borzaga and Defourny, 2001) is structured along three axes: (1) the economicentrepreneurial dimension presupposes that social enterprises have a continuous activity producing goods or services, partially using costly production factors (e.g. paid work), having a high degree of autonomy and a significant level of economic risk; (2) the social dimension presumes that social enterprises pursue an explicit social aim of serving the community (providing "common goods") or a specific group of people, producing goods or services characterized by a general-interest nature (Borzaga and Fazzi, 2011); (3) the ownership-governance dimension assumes the collective dynamics that involves people belonging to a community or to a group that share certain needs or aims and a decision-making process not based on capital ownership, also involving customers and stakeholders, a democratic management style and a non-distribution constraint, avoiding profitmaximization behaviours (Defourny and Nyssens, 2012).

It is worth underlining that social enterprises have a wide-ranging potential for the development of modern economic systems and the transformations they are generating are especially evident in their contribution to welfare and local development. Indeed, social enterprises may contribute directly or indirectly to the economic development of the territories in which they operate: generating employment and income, they directly give support to local development; while solving problems of the community and giving beneficiaries the possibility to become economically active, they indirectly promote economic growth. Thus, social enterprises may rise in order to strengthen 
the economy of a community (mainly in peripheral geographical areas or in marginal productive sectors), organizing productive activities that generate income and employment starting from local underutilized or abandoned resources. It is the case, for example, of those social enterprises that organize activities to be inserted in wider economic circuits utilizing cultural, touristic, agricultural or environmental resources that promote local development and social cohesion (Borzaga and Fazzi, 2011) or those social entities that are engaged in the reuse of the goods confiscated to criminal organizations (Mosca and Musella, 2013; Mosca, 2018).

In this regard, Borzaga and Tortia (2009) underline that it is precisely the typology of the services produced and their positive externalities at the local level that strengthen the relevance of social enterprises for local development as: (1) they are able to socialize resources for the production of public goods and services that are meritorious and beneficial for the public, overcoming market and contract imperfections through their multi-stakeholder model and through the construction of networks of personal relations; (2) the production of socially oriented services is brought nearer and tailored to local needs, involving "embeddedness" and proximity hardly reproduced by public provision and by for-profit firms; (3) these organizations create new employment at the local level mainly favouring subjects that have difficulty in moving across localities and in finding jobs; (4) their different allocation modalities support the reduction of poverty, inequality and welfare costs as negative externalities are converted into development objectives; (5) endogenous development allows the valorisation of objectives that are strategic for the locality through the utilization of resources like the environmental patrimony, voluntary labour, the cultural and historical patrimony and the like; (6) positive externalities, mainly in the form of better social trust relations, sustain the accumulation of social capital, which, in turn, helps the implementation of culturally driven models of sustainable development. Definitively, social enterprises cover an active role in local development since they are able to produce services that respond to social needs, taking into account the demands coming from the local community, and being understood as "a collector of instances of social and collective needs that, when fulfilled, allow a better match between economic growth and the needs of the local actors" (Borzaga and Tortia, 2009: 19).

\section{The cultural and creative economy}

In the last decades, the rise of sectors related to the cultural and creative economy (Caves, 2000) forced to redefine this new era of capitalism as "cognitive-cultural economy" (Scott, 2007). Actually, studies on the importance of the creative economy in urban regeneration began in the 1990s when new information and communication technologies and the economic crisis of traditional sectors draw the attention of scholars and policy-makers to the concepts of culture, creativity, creative people and professionals and, over time, to cultural and creative industries. Along these lines of inquiry, a number of scholars developed ideas about the cultural economy of cities (Scott, 1996; Pratt, 1997), which were rapidly intertwined with works on the creative city (Florida, 2002). 
Initially, Landry and Bianchini (1995) underline that cities historically needed creativity to work as markets, trading and production centres, with their critical mass of entrepreneurs, artists, intellectuals, students, administrators and power brokers. In particular, artists and cultural organizations were often identified as urban agents that participate to raise the vitality and the character of cities (Landry et al., 1996). Furthermore, artistic and cultural activities became an increasingly important part of urban regeneration also because of their emphasis on local people as principal asset through which renewal could be achieved. In this regard, Landry et al. (1996) recognize the arts as able to engage people's creativity, lead to problem solving, enable dialogue, imagine possible futures and offer self-expression, which is an essential feature of the active citizenship.

However, this phase is characterized by the highly influential work of Florida (2002), which discusses the impact of human capital and "creative classes" on urban and regional development. Florida (2002) points out that cities need to attract the creative class in order to ensure successful development: as the economy is transformed, creative occupations grow and firms orient themselves to attract the creative class. In this perspective, creative people are the engine of economic growth and prefer places that are innovative, diverse and tolerant: they move towards the so called "creative centres" which have a high concentration of creative class people and of creative economic outcomes in the form of innovations and high-tech industry growth. These centres succeed because creative people want to live there, mainly attracted by high-quality experiences, openness to diversity and opportunity to validate their identities as creative.

Analysing the urban scale, however, Scott (2006) points out that as even more employment in cities is dominated by high-end segments of the new economy, cultural amenities (such as museums, art galleries, concert halls, multifaceted entertainment districts) are often present and combined with up-scale streetscapes, shopping facilities and residential enclaves. Thus, stressing the main economic mechanisms that underlie creative cities, Scott argues that deep social divisions of labour lie at the root of functionally distinctive clusters of economic activity which are expressed in vertically disintegrated networks of production units tied together in relations of specialization and complementarity (Scott, 2006). In this new economy, these networks are frequently dominated by big firms that play a role in financing and coordinating the activities of a large number of small and medium units that typically constitute the majority of nodes in any localized web of interrelated producers.

A slightly different perspective is provided by Lazzeretti (2009) who defines creativity as the "creative capacity of culture" and argues that culture is not only seen as a basic element for economic development, but also as a source for innovation as it has the power to revitalize cities, districts, sectors, professions and goods through the generation of new ideas, cross-fertilization and serendipity. Thus, the principal paths of development for the creative capacity of culture are identified in: (1) the urban renewal specifically devoted to urban regeneration strategies such as city branding, physical renovation and culture-led strategies; (2) the economic renewal based on the idea that culture can rejuvenate not only places, but also economic industries, products, professions and sectors that are 
mature or declining; (3) the cross-fertilization built upon innovation of ideas between industries, as well as between economic actors and the broader community; (4) the serendipity, i.e. the discovery of an unusual correlation that is the basis for innovative ideas which may be connected with new uses for a product, diversification or technological correlations.

In this context, evidently, cultural and creative industries represent significant elements: Landry et al. (1996) define the cultural industries as those that include the performing arts, music, the visual arts, the audio-visual and media sectors, the publishing and digital technology. However, they also include those sectors where the creative input is a means of enhancing the value of other productsdesign, industrial design, fashion, the graphic arts, advertising and the craft sector-whose skills, ideas and methods of working are crucial in helping the cultural area to develop. Throsby (2001), conversely, formulates a concentric circle model of cultural industries, with the creative arts lying at the core and other cultural industries (such as publishing, advertising and tourism) forming circles around this core. Also Throsby, however, stresses that artistic and cultural industries may have a pervasive role in urban regeneration through the fostering of community identity, creativity, cohesion and vitality via their characteristics and practices that define the city and its citizens. On the other hand, Towse (2003), signals that cultural industries are those that mass-produce goods and services with sufficient artistic content to be considered creative and culturally significant. However, the creative economy was subjected to a particular shift from "cultural" to "creative industries" (Flew and Cunningham, 2010): this term was applied to a much wider productive set compared to that of cultural industries, including goods and services that depend on innovation, research and software development. The Department of Culture, Media and Sport in the UK (DCMS, 2001) proposes the following definition of creative industries: "those activities that have their origin in individual creativity, skill and talent and which have a potential for wealth and job creation through the general exploitation of intellectual property" (DCMS, 2001: 5).

From these lines of research, also raises the debate about "cultural and creative clusters". De Propris and Hypponen (2008) define a creative cluster as a place that brings together: communities of creative people; economic efficiencies derived from external and agglomeration economies; a thick, open and ever-changing network of interpersonal exchanges. Actually, in the 1990s many cities saw a wave of flagship museums and art centres growing in their downtowns within larger redevelopment projects also focused on high-rise office development combined with leisure options. Indeed, artistic and cultural activities tend to cluster in specific urban areas, also incorporating a great variety of entertainment elements such as bars, restaurants, cultural retail spaces, fitness complexes and the like (Mommaas, 2004).

Conversely, scholars that focus on "cultural and creative districts" (Santagata, 2006; Cooke and Lazzeretti, 2008) underline that whereas the industrial district model focuses on decentralized, vertical integration (an increasing level of coordination among firms operating within the same value chain), the cultural district model emphasizes horizontal integration (increasing levels of coordination among firms belonging to different value chains). Furthermore, differences between cluster- and district-oriented approaches also appear in another crucial domain: in the cluster, the 
economic dimension is the dominant one and social relationships and local identity issues seem to have secondary relevance. In the district, conversely, the social dimension is equally important as the economic one and the social fabric of interaction and exchange among local players is a keystone that keeps the production system together, particularly in the case of small and medium enterprises, which are often linked by personal or family ties (Sacco et al., 2013).

Nevertheless, despite their international success, many of the previous theories attracted severe critiques from numerous scholars. As reference, Scott (2010) defines the creative city as characterized by a widening economic and social gap between upper and lower classes of the labour force and underlines that this model of socio-economic development and its complex urban conditions implies an evident socio-spatial segmentation that characterizes the major centres of the global cultural economy.

On the other hand, Markusen's critique (2006) to the notion of the creative class focuses on the fuzzy causal logics about its relationship with urban growth: the formation, location, urban impact and politics of creative class occupations are much more complex and distinctive than proposed by Florida. Markusen suggests that occupations included in the creative class have very different urban preferences, politics and impacts on urban forms and community life: thus, the attractiveness of certain cities to artists is not the result of "atomistic" responses to amenities but is shaped by investment decisions that cities make in artistic spaces and organizations.

Successively, Pratt (2008) focuses on the causality between creative class and urban transformations: the creative class argument is used as a magnet to attract hi-tech industries, implying that cities must adapt themselves to the values of the creative class. Pratt (2011) highlights two types of contradictions of the creative city: first, the need to explore the outcome of such a city in consumption and production modalities; and, second, the nature of creativity and its linkage to neoliberalism as the creative city seems to be built for privileged groups, implicitly excluding others.

Finally, Leslie and Catungal (2012) criticize the creative class theory as it confines the working classes to a passive role in economic transformations. Accordingly, creative cities tend to have higher levels of social and economic polarization as the growth of creative classes seems to be accompanied by the growth of service classes which provide a range of outside services in order to meet professionals' social reproduction needs. Service classes' jobs are focused above all on sustaining the facilities and infrastructures of the urban system, implying that their work is adjusted in large degree to provide the direct and indirect demands of the creative class workers.

Relying on the previous critiques, many scholars proposed alternative models based on culture and creativity as tools of a sustainable urban regeneration. As reference, Sasaki (2010) affirms that rethinking the creative city theory implies offering creative solutions to problems of social exclusion: new policies should raise the capacity for the city as a whole to grasp the creativity inherent in art and culture to create new industries and employment opportunities. Therefore, in this view, cultural policies should be carried on through the cooperation of a broad selection of citizens, including business leaders and nonprofits, facing directly the problem of social exclusion and providing the social infrastructures to foster the active participation of citizens. Definitively, the new goal seems 
to be a closer integration of economic and social values of the cultural heritage within a model of sustainable growth that aims at social inclusion and cohesion.

Following this discourse, in order to reinforce democracy and well-being and to design new forms of "sustainable cultural capitalism" (Scott, 2008), Duxbury, Hosagrahar and Pascual (2016) remark that the role of cultural practices must be explicitly recognized, supported and integrated into comprehensive planning models. Again, culture is a key element in the success of sustainable urban development policies, as a driver of people-centred societies and a crucial element for the dynamic construction of individual and collective identities. In such a context, thus, culture is conceived both as a key tool and a core aspect of the social fabric: not only a means through which citizens feel they belong to their city, but also a tool which can empower marginalized individuals and communities to participate in social and economic life. Finally, Fusco Girard (2012) points out that a different vision of the creative city involves the idea of a city that invests in economic (wealth), ecological (environment), social (employment) and cultural resilience which allows for creative responses to changes and shocks: a resilient city is also a creative city, able to reinvent a new equilibrium against destabilizing external pressures and multiplying the potential of people to build identities and opportunities.

\section{Conclusion: merging the two approaches through the common field of social innovation}

In this conclusive paragraph we try to merge the two previous academic approaches, underlining the role of cultural third sector organizations in the urban regeneration of deprived contexts. Cultural nonprofits raised increasing interest in different research fields especially around their community-centric role; the equal access of all people to cultural opportunities; the reduction of economic barriers to cultural programming; and the general cultural access for diverse groups that distinguishes nonprofit from for-profit arts organizations. Specifically focusing on the European literature, along the 2000s, many researchers recognized a common theoretical ground for the social economy and the cultural sector around the concept of "social innovation" and its importance in local and urban development.

Moulaert et al. (2013: 16) refer to social innovation as those "acceptable progressive solutions for a whole range of problems of exclusion, deprivation, alienation, lack of wellbeing and also to those actions that contribute positively to significant human progress and development". These solutions are "forms of sustained collective action based on common purposes and social solidarities" (Moulaert et al., 2010: 11) that involve a series of concrete objectives: (1) the satisfaction of human needs and the improvement of human conditions; (2) the empowerment of the local community in terms of becoming aware of their skills and knowledge resources and of taking part to the decision-making process; (3) the changes in relations and governance practices; (4) the setting of agendas for a better future, searching for fulfilment of human existence and a better equilibrium in living together. In other words, social innovation means pursuing a community that would accede 
to universal rights and more social inclusion through the improvement of social relations, both between individuals and people and between classes and other social groups (Moulaert et al., 2013).

Crucial in the conceptualization of social innovation is its relationship with local development, especially at the urban scale: since the 1970s, around the world many bottom-up initiatives raised through socially oriented and area-based collective actions in reaction to neoliberal development strategies centred on making cities more market-feasible and competitive through physical renewal. These initiatives were generally led by various types of public actors (mainly civil society) and often followed an integrated logic of development, trying to address a diverse range of problems and needs through coordinated action. In these experiences, social innovation was recognized as an anchor concept for urban regeneration because of its focus on innovation in social relations, as well as in meeting human needs, highlighting issues of solidarity and cooperation and economic, human, cultural diversity, situated both outside and in combination with market.

Spatially speaking, the approach of social innovation in territorial development associated with Moulaert (2000) stresses local development problems, especially in the diffusion of skills and experiences in the formation of urban policies or the lack of integration between spatial levels or even the neglect of the needs of deprived groups within urban society. To overcome these problems, Moulaert (2009) suggests organizing urban development along the lines of the "integrated area development" approach that brings together various spheres of social development and the roles of the main actors by structuring them around the principle of social innovation. This principle links the satisfaction of human needs to innovation in social relations of governance and is based on the satisfaction of basic needs of local communities which should be guaranteed by the combination of several processes: (1) the revealing of these needs by social movements and institutional dynamics, within and outside the state sphere; (2) the integration of deprived citizens into the labour market and the local social economy production systems; (3) the education and professional training leading to a more active participation in decision-making on the future of a territory.

On the other hand, social economy organizations are considered important contributors to a better understanding of social innovation in the contemporary economy. In fact, as seen, social economy is rooted in the satisfaction of local communities' unmet needs that the public sector and the market increasingly fail to satisfy, especially when potential users are financially deprived citizens or groups operating at the margins of society. In this regard, Moulaert and Nussbaumer (2005) consider the social economy as part of social innovation at the local level as it rests on two related pillars: (1) institutional innovation (innovation in social relations and in governance comprising empowerment dynamics) which includes cultural emancipation, interpersonal and intergroup communication, preference revealing, decision-making mechanisms, systems development and coordination, community dynamics, organization of the local social economy and its employment relations; (2) innovation in the sense of the social economy, i.e. the satisfaction of different needs in local communities that not only refer to food, clothing, health and housing, but also to the self-determination of individuals who require education, employment and good governance. 
Analysing more specifically the relations between social innovation, social economy and social enterprises, Defourny and Nyssens (2013) completely agree with Moulaert and Nussbaumer (2005) about the fact that social innovation at the local level rests on institutional innovation and innovation in the sense of the social economy, underlining that social innovation seems to be at the heart of the literature around the social enterprise concept. Indeed, the existing links between the corpus of social enterprise research and the social innovation dynamics relate to three major features: the satisfaction of human needs which is the basic criteria of producing goods and selling services with an explicit aim to benefit the community; the relations among people and social groups; and the empowerment of people trying to fulfil their needs, which are deeply linked to the governance pillar of the EMES approach to social enterprises.

From here, it can be concluded that social enterprises prove to be innovative not only in terms of processes and services delivered, but also in terms of their ability to plan interventions in diverse social contexts: different experiences demonstrated how these organizations regenerated urban contexts through protecting the environment, reorganizing spaces or valorising the historical, cultural and urban patrimony (Sacchetti, Christoforou and Mosca, 2018). For this reason, we now shift the focus to the role of social economy organizations in urban regeneration strategies that foster social innovation.

In this regard, it seems that the potential for social economy organizations in urban regeneration goes beyond the solely valorisation of physical spaces, involving relational and immaterial assets: these actors seem to combine economic, urban, environmental and social regeneration, pursuing public interest objectives in relation to the use of physical spaces. In this, urban regeneration should be understood as a process of creation not only of material capital, but also of relational capital because of the inclusive and deliberative coordination mechanisms that lie the basis of social economy (Sacchetti, 2016). In particular, coordination and cooperation that promote creativity, opportunities, social engagement, change and fulfilment, also generate social capital, emphasizing the role of development models grounded in active citizenship and recognition of mutual interests (Sacchetti and Campbell, 2014).

In this respect, as social economy organizations apply in their structure and practices the values of cooperation, they can contribute to the promotion and resilience of cooperative attitudes within communities (Sacchetti, 2014), generating positive effects across societies at large and transforming the value of cooperation for the common good into practical business solutions (Sacchetti and Tortia, 2014). Furthermore, participation and cooperation play a crucial role in regeneration "by enabling local actors and communities of interest to voice diverse needs and interests, including those of the marginalized and disadvantaged groups, to organize concerted efforts to discuss problems and promote solutions, and to create a public space of deliberative, democratic participation to re-assess values and priorities regarding the means and ends of development and welfare" (Sacchetti, Christoforou and Mosca, 2018: 1). These cooperative solutions provided by social economy organizations go beyond the use of material resources and the production of monetary outcomes and involve the use and production of 
relational goods which are intangible elements characterized by communicative and affective nature, produced through encounters and interactions, values of inter-generational solidarity, respect for the environment and behavioural norms of reciprocity and cooperation (Borzaga and Tortia, 2017).

Finally, as underlined by Cottino and Zandonai (2012), social enterprises carrying out urban regeneration activities are interesting examples of the application of social innovation as they aim to reconvert physical structures toward new forms of community assets. In fact, their activities are considered innovative as they valorise a wide range of resources and favour their coordinated use toward collective interest objectives (Cottino and Zeppetella, 2009). In this, social innovation represents the guide-concept for the promotion of systemic change actions as it consists of new ideas (products, services and models) that simultaneously satisfy social needs, generating new relations and collaborations. The fact that the focus is on the creation of collaboration and coordination amongst different subjects remarks the centric role that social economy organizations play, operating at the intersection between public, private and nonprofit sectors.

A different point of view concerns the role of the arts in promoting social innovation and constructing a socially creative environment. Social innovation is closely related to artistic production, as it constitutes an alternative to traditional ways of doing things, an avantgarde process and an unconventional response to specific needs, also considering that artistic expressions entail recognition of collective signs of belonging to groups, communities, cities and neighbourhoods.

Moreover, cultural resources also constitute important driving forces in bringing about social innovation: culture is understood as a "voice" for deprived populations, communicating desperation but also calling for consideration and respect. In this regard, different case studies (André, Abreu and Carmo, 2013) show how the implementation of cultural and artistic events can represent a process of social innovation, capable of empowering populations living in peripheral areas and leading them to express their voices through a dialogue with artists and especially through participation in collective art productions. These experiences demonstrate that the construction of a creative environment results from the process of using art resources to enhance local mobilization and expression of wishes and symbols. The presence of these elements contributes to stimulate diversity - basic condition for social innovation - within a framework marked by actions aimed at increasing reciprocal responsibility (collective productions involving local residents; realization of accessible cultural events), overcoming tensions and conflicts among social groups and reinforcing solidarity and inclusion.

Definitively, the arts and culture may reinforce the social identity and the sense of belonging shared by citizens through knowing the same artefacts, using the same symbols and going collectively toward the same performance experience. In this, "the contribution of the arts and culture to sociocultural and economic development of a given space is based on behaviours of cooperation and organization between the territorial actors. It can certainly play a fundamental role in the integration of excluded or marginalized individuals and communities but also in developing social and human 
capital" (Tremblay and Pilati, 2013: 76). On the other hand, the arts and culture may perform as both a cohesive and a networking social factor, answering various human and social needs to improve quality of life and wellbeing, going beyond projects of urban revitalization centred only on economic aspects, but including the social dimension.

Consequently, a new policy aim seems to be that of launching projects of social innovation and urban regeneration through activities related to the arts and culture and led by social economy organizations as the link among these elements of the urban reality appears even clearer and crucial. In fact, innovative strategies should include both place-oriented and people-oriented dimensions, as physical, economic, and social aspects should be included in a holistic approach to the city and its community. In particular, an innovative policy of urban regeneration should provide a basic standard of living as well as the necessary opportunities and resources to guarantee the satisfaction of primary needs of residents, allowing them to participate economically, socially and culturally (Sasaki, 2010). In this regard, the provision of adequate infrastructures, the integrate action of different actors, the inclusion of real and diverse places of creativity can all be identified as remarkable tools of a creative urban approach that aims to foster the inclusive participation of citizenry and to help declining areas to recover. This new way of thinking should also constructively engage actors such as nonprofits, cultural associations, social cooperatives, social enterprises and common citizens in innovative (multistakeholder) urban governance models that give raise to regeneration policies that overcome the neoliberal framework, especially after the failures of traditional models in building inclusive and cohesive urban strategies.

In conclusion, starting from the proposal to joint two strands of literature under the common ground of social innovation, and in order to advance concrete research questions to be tested in further field research around the role that cultural third sector organizations may play in urban regeneration strategies, we try to summarize the main elements of our approach in Table 1. Concretely, merging Myrdal's backwash and spread effects, Hirschman's exit-voice problem and Polanyi's reciprocity mechanism, we can apply these concepts to the urban scale and formulate the following questions: (1) Are third sector organizations able to attract resources in peripheral neighbourhoods of the city and which mechanisms do they use in order to efficiently allocate these resources among local residents? (2) When market and state forces fail to attract (or hold) citizens and impede (or stop) exit in particular neighbourhoods, are third sector organizations able to give "voice" to local communities' needs and requests and which tools do they utilize to foster social innovation? (3) Which practices should be implemented in order to enable third sector organizations to access the economic and social resources they need to effectively operate as providers of specific services and players of urban regeneration in depressed contexts? Further empirical research trough qualitative case studies is needed in order to answer the previous questions and deeply understand potentialities and limits of third sector organizations engaged in the cultural and creative economy and their role as engines of urban regeneration in contested and depressed neighbourhoods. 
Table 1. Theoretical framework. Summary table

\begin{tabular}{|c|c|c|}
\hline References & Main concepts & Research questions \\
\hline $\begin{array}{l}\text { Myrdal (1957); } \\
\text { Hirschman (1958) }\end{array}$ & $\begin{array}{l}\text { Backwash-spread effects and polarization- } \\
\text { trickling down effects as sources of } \\
\text { development-underdevelopment }\end{array}$ & \multirow{2}{*}{$\begin{array}{l}\text { Are third sector organizations able } \\
\text { to attract resources in peripheral } \\
\text { neighbourhoods of the city and which } \\
\text { mechanisms do they use in order to } \\
\text { efficiently allocate these resources among } \\
\text { local residents? }\end{array}$} \\
\hline Colby (1933) & $\begin{array}{l}\text { Centripetal-centrifugal forces as key } \\
\text { elements explaining the forming and } \\
\text { development of cities }\end{array}$ & \\
\hline Hirschman (1970) & $\begin{array}{l}\text { Exit, voice and loyalty applied to urban, } \\
\text { political and social scales }\end{array}$ & \multirow{3}{*}{$\begin{array}{l}\text { When market and state forces fail to attract } \\
\text { (or hold) citizens and impede (or stop) exit } \\
\text { in particular neighbourhoods, are third } \\
\text { sector organizations able to give "voice" to } \\
\text { local communities' needs and requests and } \\
\text { which tools do they utilize to foster social } \\
\text { innovation? }\end{array}$} \\
\hline Young (1974) & $\begin{array}{l}\text { Exit-voice framework used along spatial } \\
\text { and vertical dimensions }\end{array}$ & \\
\hline Sharp (1984) & $\begin{array}{l}\text { Voice as contact with local governments or } \\
\text { as neighbours solving problems }\end{array}$ & \\
\hline
\end{tabular}

Polanyi (1944)

Moulaert et al. (2013)

Borzaga, Sacchetti and Tortia (2019)
Self-regulating markets as separated from non-economic institutions of society and based on economic incentives

Social enterprises as actors of resource coordination through cooperative pacts based on reciprocity

Third sector organizations pursuing the entanglement of social and economic spheres, going beyond material resources
Which practices should be implemented in order to enable third sector organizations to access the economic and social resources they need to effectively operate as providers of specific services and players of urban regeneration in depressed contexts?

\section{References}

André, I., Abreu, A. \& Carmo, A. (2013). Social innovation through the arts in rural areas: the case of Montemor-oNovo. In: F. Moulaert, D. MacCallum, A. Mehmood \& A. Hamdouch (Eds.), The international handbook on social innovation. Social innovation, collective action and transdisciplinary research. Cheltenham: Edward Elgar: pp. 242-258. DOI: https://doi.org/10.4337/9781849809993.00032

Anheier, H. (2014). Nonprofit organizations: theory, management, policy. London: Routledge. DOI: https:/doi. org/10.4324/9781315851044

Ben-Ner, A. (1986). Nonprofit organizations: why do they exist in market economies? In: S. Rose-Ackerman (Ed.), The economics of nonprofit institutions: studies in structure and policy. Oxford: Oxford University Press: pp. 94-113.

Ben-Ner, A. \& Van Hoomissen, T. (1992). An empirical investigation of the joint determination of the size of the forprofit, nonprofit and government sectors, Annals of Public and Cooperative Economics, 63: 469-94. DOI: https:// doi.org/10.1111/j.1467-8292.1992.tb02098.x 
Borzaga, C. \& Defourny, J. (2001). The emergence of social enterprises. London: Routledge. DOI: https://doi. org/10.4324/9780203164679

Borzaga, C. \& Fazzi, L. (2011). Le imprese sociali. Roma: Carocci.

Borzaga, C. \& Tortia, E. (2009). Social enterprises and local economic development. In: E. Clarence \& A. Noya (Eds.), The changing boundaries of social enterprises. Paris: OECD: pp. 195-228. DOI: https://doi. org/10.1787/9789264055513-6-en

Borzaga, C. \& Tortia, E. (2017). Co-operation as coordination mechanism: a new approach to the economics of co-operative enterprises. In: J. Michie, J. Blasi \& C. Borzaga (Eds.), The Oxford handbook of mutual, cooperative, and co-owned business. Oxford: Oxford University Press: pp. 55-75. DOI: https://doi.org/10.1093/ oxfordhb/9780199684977.013.5

Borzaga, C., Sacchetti, S. \& Tortia, E. (2019). The institutions of livelihood and social enterprise systems, Euricse Working Paper Series, 109|19. DOI: https://doi.org/10.2139/ssrn.3519810

Caves, R. (2000). Creative industries: contracts between art and commerce. Harvard: Harvard University Press.

Colby, C. (1933). Centrifugal and centripetal forces in urban geography, Annals of the Association of American Geographers, 23(1): 1-20. DOI: https://doi.org/10.1080/00045603309357110

Cooke, P. \& Lazzeretti, L. (Eds) (2008). Creative Cities, Cultural Clusters and Local Development. Cheltenham: Edward Elgar. DOI: https://doi.org/10.4337/9781847209948

Cottino, P. \& Zandonai, F. (2012). Progetti d'impresa sociale come strategie di rigenerazione urbana: spazi e metodi per l'innovazione sociale, Euricse Working Paper Series, 42|12.

Cottino, P. \& Zeppetella, P. (2009). Creatività, sfera pubblica e riuso sociale degli spazi. Forme di sussidiarietà orizzontale per la produzione di servizi non convenzionali, Paper Cittalia, 4: 1-61.

DCMS (2001). Creative Industries Mapping Document. London, UK: Department of Culture, Media and Sport.

De Propris, L. \& Hypponen, L. (2008). Creative clusters and governance: the dominance of the Hollywood film cluster. In: P. Cooke \& L. Lazzeretti (Eds.), Creative Cities, Cultural Clusters and Local Development. Cheltenham: Edward Elgar: pp. 340-371.

Defourny, J. (2001). Introduction. From third sector to social enterprise. In: C. Borzaga \& J. Defourny (Eds.), The emergence of social enterprises. London: Routledge: pp. 1-28.

Defourny, J. \& Nyssens, M. (2010). Conceptions of social enterprise and social entrepreneurship in Europe and the United States: convergences and differences, Journal of Social Entrepreneurship, 1(1): 32- 53. DOI: https://doi. org/10.1080/19420670903442053

Defourny, J. \& Nyssens, M. (2012). Conceptions of social enterprise in Europe: A comparative perspective with the United States. In: B. Gidron, \& Y. Hasenfeld (Eds.), Social enterprises: an organizational perspective. New York: Palgrave-Macmillan: pp. 71-90. DOI: https://doi.org/10.1057/9781137035301_4

Defourny, J. \& Nyssens, M. (2013). Social innovation, social economy and social enterprise: what can the European debate tell us? In: F. Moulaert, D. MacCallum, A. Mehmood \& A. Hamdouch (Eds.), The international handbook on social innovation: collective action, social learning and transdisciplinary research. London: Edward Elgar Publishing: pp. 40-52. DOI: https://doi.org/10.4337/9781849809993.00013

Defourny, J. \& Pestoff, V. (2008). Images and concepts of the third sector in Europe, EMES Working Papers, 08|02.

Duxbury, N., Hosagrahar, J. \& Pascual, J. (2016). Why Must Culture Be at the Heart of Sustainable Urban Development? United Cities and Local Governments (UCLG).

Flew, T. \& Cunningham, S. (2010). Creative industries after the first decade of debate, The Information Society, 26(2): 113-123. DOI: https://doi.org/10.1080/01972240903562753

Florida, R. (2002). The rise of the creative class: and how it's transforming work, leisure, community and everyday life. London: Basic Books. 
Fusco Girard, L. (2012). Creativity and the human sustainable city: principles and approaches for nurturing city resilience. In: L. Fusco Girard, P. Nijkamp \& T. Baycan (Eds.), Sustainable city and creativity: promoting creative urban initiatives. London: Ashgate: pp. 55-92.

Hansmann, H. (1980). The role of nonprofit enterprise, Yale Law Journal, 89(5): 835-901. DOI: https://doi. org/10.2307/796089

Hansmann, H. (1987). Economic theories of nonprofit organizations. In: W. Powell (Ed.), The nonprofit sector. A research handbook. New Haven: Yale University Press: pp. 27-42.

Hirschman, A. (1958). The strategy of economic development. Yale University Press.

Hirschman, A. (1970). Exit, voice, and loyalty. Harvard University Press.

James, E. (1987). The nonprofit sector in comparative perspective. In: W. Powell (Ed.), The nonprofit sector. A research handbook. New Haven: Yale University Press: pp. 387-415.

Landry, C. \& Bianchini, F. (1995). The Creative City. London: Comedia.

Landry, C., Greene, L., Matarasso, F. \& Bianchini, F. (1996). The art of regeneration. Urban renewal through cultural activity. London: Comedia.

Lazzeretti, L. (2009). The creative capacity of culture and the new creative milieu. In: G. Becattini, M. Bellandi \& L. De Propris (Eds.), The handbook of industrial districts. Cheltenham: Edward Elgar: pp. 281- 294.

Leslie, D. \& Catungal, J. (2012). Social justice and the creative city: class, gender and racial inequality, Geography Compass, 6(3): 111-122. DOI: https://doi.org/10.1111/j.1749-8198.2011.00472.x

Markusen, A. (2006). Urban development and the politics of a creative class: evidence from a study of artists, Environment and Planning A, 38(10): 1921-1940. DOI: https://doi.org/10.1068/a38179

Myrdal, G. (1939). Monetary equilibrium. W. Hodge Limited.

Myrdal, G. (1957). Economic theory and underdeveloped regions. London: Duckworth.

Myrdal, G. (1963). Challenge to affluence. London: V. Gollancz.

Mommaas, H. (2004). Cultural clusters and the post-industrial city: towards the remapping of urban cultural policy, Urban Studies, 41(3): 507-532. DOI: https://doi.org/10.1080/0042098042000178663

Mosca, M., (2018). The social regeneration of Mafia assets in the land of Gomorrah. The role of social cooperatives. In: S. Sacchetti, A. Christoforou \& M. Mosca (Eds.), Social regeneration and local development. Cooperation, social economy and public participation. London: Routledge: pp. 117-134. DOI: https://doi. org/10.4324/9781315302478-7

Mosca, M. \& Musella, M. (2013). L'economia sociale come antidoto all'economia criminale. Rassegna Economica, Rivista Internazionale di Economia e Territorio, 1: 97-108.

Moulaert, F. (2000). Globalization and integrated area development in European cities. Oxford: Oxford University Press.

Moulaert, F. (2009). Social innovation: institutionally embedded, territorially (re)produced. In: D. MacCallum, F. Moulaert, J. Hillier \& S. Vicari (Eds.), Social innovation and territorial development. Ashgate Publishing Ltd: pp. $11-24$.

Moulaert, F., MacCallum, D., Mehmood, A. \& Hamdouch, A. (2013). General introduction: the return of social innovation as a scientific concept and a social practice. In: F. Moulaert, D. MacCallum, A. Mehmood \& A. Hamdouch (Eds.), The international handbook on social innovation: collective action, social learning and transdisciplinary research. London: Edward Elgar Publishing: pp. 1-6. DOI: https://doi.org/10.4337/9781849 809993.00008

Moulaert, F., Martinelli, F., Swyngedouw, E. \& Gonzales, S. (2010). Can the neighbourhoods save the city? Community Development and Social Innovation. London: Routledge. DOI: https://doi.org/10.4324/9780203849132

Moulaert, F. \& Nussbaumer, J. (2005). Defining the social economy and its governance at the neighbourhood level: a methodological reflection, Urban Studies, 42(11): 2071-2088. DOI: https://doi.org/10.1080/420980500279752 
Patti, D. \& Polyak, L. (2018). Funding the cooperative city. From knowledge network to local action, Rivista Italiana Transdisciplinare di Studi Urbani, 3: 238-248.

Polanyi, K. (1944). The Great Transformation: the political and economic origins of our time. New York: Rinehart.

Polanyi, K. (1977). The livelihood of man. Edited by Pearson H., New York: Academic Press.

Pratt, A. (1997). The cultural industries production system: a case study of employment change in Britain, 1984-91, Environment and Planning A, 29(11): 1953-1974. DOI: https://doi.org/10.1068/a291953

Pratt, A. (2008). Creative cities: the cultural industries and the creative class, Geografiska Annaler Series B, Human Geography, 90(2): 107-117. DOI: https://doi.org/10.1111/j.1468-0467.2008.00281.x

Pratt, A. (2011). The cultural contradictions of the creative city, City, Culture and Society, 2(3): 123-130. DOI: https:// doi.org/10.1016/j.ccs.2011.08.002

Rose-Ackerman, S. (1996). Altruism, nonprofits, and economic, Journal of Economic Literature, 34(2): 701-728.

Sacchetti, S. (2014). Deliberative praxis, creation of public spaces and community welfare: development model of a small Italian town. Management, Work and Organization, University of Stirling Working Papers.

Sacchetti, S. (2016). Oltre la rigenerazione di spazi: imprese sociali e sviluppo locale. Iris Network.

Sacchetti, S. \& Campbell, C. (2014). Creating space for communities: social enterprise and the bright side of social capital, Journal of Entrepreneurial and Organizational Diversity, 3(2): 32- 48. DOI: https://doi.org/10.5947/ jeod.2014.012

Sacchetti, S., Christoforou, A. \& Mosca, M. (2018). Introduction. In: S. Sacchetti, A. Christoforou \& M. Mosca (Eds.), Social regeneration and local development. Cooperation, social economy and public participation. London: Routledge: pp. 1-17. DOI: https://doi.org/10.4324/9781315302478-1

Sacchetti, S. \& Tortia, E. (2014). The extended governance of cooperative firms: inter-firm coordination and consistency of values, Annals of Public and Cooperative Economics, 87(1): 93-116. DOI: https://doi.org/10.1111/apce.12058

Sacco, P., Ferilli, G., Tavano Blessi, G. \& Nuccio, M. (2013). Culture as an engine of local development processes: systemwide cultural districts I: theory, Growth and change, 44(4): 555-570. DOI: https://doi.org/10.1111/grow.12020

Salamon, L. (1995). Partners in public service: government-nonprofit relations in the modern welfare state. Johns Hopkins University Press.

Salamon, L. \& Anheier, H. (1998). Social origins of civil society: explaining the nonprofit sector cross- nationally, Voluntas, 9(3): 213-47.

Santagata, W. (2006). Cultural districts and their role in economic development. In: V. Ginsburgh \& D. Throsby (Eds.), Handbook of the economics of art and culture. Amsterdam: Elsevier: pp. 1100-1119.

Sasaki, M. (2010). Urban regeneration through cultural creativity and social inclusion: rethinking creative city theory through a Japanese case study, Cities, 27(1): 3-9. DOI: https://doi.org/10.1016/j.cities.2010.03.002

Scott, A. (1996). Regional motors of the global economy, Futures, 28(5): 391-411. DOI: https://doi.org/10.1016/00163287(96)00016-X

Scott, A. (2006). Creative cities: conceptual issues and policy questions, Journal of Urban Affairs, 28(1): 1-17. DOI: https://doi.org/10.1111/j.0735-2166.2006.00256.x

Scott, A. (2007). Capitalism and urbanization in a new key? The cognitive-cultural dimension, Social Forces, 85: 14651482. DOI: https://doi.org/10.1353/sof.2007.0078

Scott, A. (2008). Global city-regions. Trends, theory, policy. Oxford: Oxford University Press.

Scott, A. (2010). Cultural economy and the creative field of the city, Geografiska Annaler, Series B, Human Geography, 92(2): 115-130. DOI: https://doi.org/10.1111/j.1468-0467.2010.00337.x

Sharp, E. (1984). Exit, voice and loyalty in the context of local government problems, Western Political Quarterly, 37(1): 67-83. DOI: https://doi.org/10.1177/106591298403700106 
Throsby, D. (2001). Economics and culture. New York: Cambridge University Press.

Towse, R. (2003). A handbook of cultural economics. Edward Elgar Publishing. DOI: https://doi.org/10.4337/9781781008003

Tremblay, D. \& Pilati, T. (2013). Social innovation through arts and creativity. In: F. Moulaert, D. MacCallum, A. Mehmood \& A. Hamdouch (Eds.), The international handbook on social innovation. Social innovation, collective action and transdisciplinary research. London: Edward Elgar Publishing: pp. 67-79. DOI: https://doi.org/10.433 7/9781849809993.00015

Young, D. (1974). Exit and voice in the organization of public services, Social Science Information, 13(3): 49-65. DOI: https://doi.org/10.1177/053901847401300303

Young, D. (1983). If not for profit, for what? A behavioral theory of the nonprofit sector based on Entrepreneurship. Massachusetts: Lexington Books.

Weisbrod, B. (1975). Toward a theory of the voluntary, non-profit sector in a three-sector economy. In: E. Phelps (Ed.), Altruism, morality and economic theory. New York: Russell Sage: pp. 171-195.

Weisbrod, B. (1977). The voluntary nonprofit sector: an economic analysis. Massachusetts: Lexington Books.

Weisbrod, B. (1988). The nonprofit economy. Cambridge: Harvard University Press. 